\title{
PENGARUH KEMAJUAN TEKNOLOGI TERHADAP VOLUME PEJUALAN RITEL DI KOTA MOJOKERTO
}

\author{
Rachmad Sholeh ${ }^{1}$ dan Khasbulloh Huda ${ }^{2}$ \\ ${ }^{1), 2)}$ Staf Pengajar Fakultas Ekonomi Universitas Mayjen Sungkono
}

\begin{abstract}
The development of the business world today is increasingly diverse and competitive, the pace of development is very difficult to predict, so having the right strategy is the key for a company to continue to compete and survive. Along with technological advancements and the development of communication suggestions, the company is utilizing these technological advances as a marketing strategy tool to promote its products. Given the growth of buying and selling transactions in the network or online in Indonesia at this time is very rapid, with this being used by companies to market and promote via the internet.

This study aims to determine the effect of the implementation of technological progress on retail sales volumes. The development of information technology that is growing very rapidly now influences the community in supporting various business activities both large and small so that it can be known globally. The most obvious impact is that besides being known, it can also increase sales volume. Digital Marketing is one of the very large marketing media that has an influence. Using digital marketing in this case is social media and E-commerce. The most widely used social media is Facebook, Twitter and Instagram. The subjects in this study were retail owners, managers, and employees who were selected by purpose sampling.
\end{abstract}

\section{Keywords: Social Media, E-Commerce, Sales Volume}

\begin{abstract}
ABSTRAK
Perkembangan dunia usaha saat ini semakin beragam dan kompetitif, laju perkembangan sangat sulit diprediksi, sehingga memiliki strategi yang tepat adalah kunci bagi suatu perusahaan agar dapat terus bersaing dan bertahan. Seiring dengan kemajuan teknologi dan perkembangannya saran komunikasi, perusahaan memanfaatkan kemajuan teknologi tersebut sebagai alat strategi pemasaran untuk mempromosikan produknya. Mengingat Pertumbuhan transaksi jual beli dalam jaringan atau online di Indonesia pada saat ini sangat pesat, dengan hal ini dimanfaatkan oleh perusahaan untuk memasarkan dan mempromosikan melalui internet.

Penelitian ini bertujuan untuk mengetahui pengaruh implementasi kemajuan teknologi terhadap volume penjualan Ritel.Perkembangan teknologi informasi yang berkembang sangat pesat saat ini berpengaruh bagi masyarakat dalam mendukung berbagai kegiatan bisnis baik besar maupun kecil agar dapat dikenal secara global. Dampak yang paling nyata adalah selain dikenal juga dapat meningkatkan volume penjualan. Digital Marketing adalah salah satu media pemasaran yang sangat besar memberikan pengaruh. Dengan menggunakan digital marketing dalam hal ini adalah sosial media dan E-commerce. Media sosial yang paling banyak digunakan adalah Facebook, Twitter dan Instagram. Subyek dalam penelitian ini adalah pemilik, pengelola dan karyawan ritel yang dipilih secara purpose sampling.
\end{abstract}

\section{Kata Kunci : Media Sosial, E-Commerce, Volume Pejualan}

\section{PENDAHULAN}

Perkembangan dunia usaha saat ini semakin beragam dan kompetitif, laju perkembangan sangat sulit diprediksi, sehingga memiliki strategi yang tepat adalah kunci bagi suatu perusahaan agar dapat terus bersaing dan bertahan.

Berkembangnya internet banyak hal yang timbul, salah satunya adalah berbelanja produk atau jasa secara online, berbelanja secara online telah menjadi alternatif cara pembelian produk atau pun 
jasa, penjualan secara online berkembang baik dari segi pelayanan, efektifitas, keamanan dan juga popularitas. (Laohapensang, 2009).

Pertumbuhan transaksi jual beli dalam jaringan atau online di Indonesia pada saat ini sangat pesat. Teknologi informasi sangat berkembang pesat. Berbagai kegiatan bisnis kecil sampai kegiatan bisnis besar memanfaatkan perkembangan ini untuk menjalankan usahanya. Banyaknya competitor menjadi pertimbangan bagi para pengusaha untuk masuk dalam persaingan yang sangat ketat. Strategi pemasaran dan media yang tepat digunakan untuk bisa meraih pasar yang dituju sehingga volume penjualan selalu meningkat. Digital Marketing adalah salah satu media pemasaran yang saat ini sedang banyak diminati oleh masyarakat untuk medukung berbagai kegiatan yang dilakukan. Mereka sedikit demi sedikit mulai meninggalkan model pemasaran konvesional/tradisional beralih ke pemasaran modern yaitu digital marketing. Dengan digital marketing komunikasi dan transaksi dapat dilakukan setiap waktu/ real time dan bisa meng-global atau mendunia. Dengan jumlah pengguna social media berbasis chat ini yang banyak dan semakin hari semakin bertambah membuka peluang bagi Peritel untuk mengembangkan pasarnya dalam genggaman smartphone.

Salah satu potensi yang dapat dimanfaatkan adalah teknologi informasi. Perkembangan teknologi informasi saat ini membuat manusia sudah tidak lagi mempermasalahkan batas jarak, ruang dan waktu. Teknologi informasi melahirkan internet, internet menawarkan banyak manfaat bagi Peritel untuk meningkatkan pemasaran produknya. Selain itu juga internet memberikan manfaat meningkatkan kesempatan Peritel untuk bekerjasama dengan pengusaha lainya. Salah satu teknologi internet yang sedang berkembang pesat dan sangat berpotensi untuk mendorong pemasaran peritel adalah media sosial. Media sosial memiliki potensi menghubungkan banyak orang dengan mudah dan gratis. Media Sosial kini telah menjadi trend dalam komunikasi pemasaran. Menurut Kaplan dan Haenlein (2010), media sosial adalah sekelompok aplikasi berbasiskan internet yang dibangun berdasarkan kerangka pikiran ideologi dan teknologi dari web 2.0, dan memungkinkan terbentuknya kreasi pertukaran isi informasi dari pengguna internet. Web 2.0 adalah dasar terbentuknya sosial media (Carlsson, 2010). Contoh-contoh media sosial yang berkembang saat ini adalah : twitter, facebook, myspace, youtube, instagram, path, whatsapp, line, dll. Mengingat pentingnya informasi tentang bagaimana penggunaan media sosial bagi Peritel dan manfaatnya, maka perlu dilakukan suatu penelitian observasional.

Menurut Hidayat (2008:5) perdagangan eletronik (E-Commerce : electronic commerce) adalah bagian dari e-lifestyle yang memungkinkan transaksi jual beli dilakukan secara online dari sudut tempat manapun. Tujuan ritel adalah meningkatkan penjualan produk, karena penjualan merupakan sumber pendapatan Peritel agar dapat terus bertahan dan mengembangkan ritennya. Penjualan yang meningkat tiap tahun menjadi gambaran bahwa ritel berhasil mempromosikan produknya kepasaran. Jadi e-commerce diharapkan dapat menunjang keberhasilan Peritel dalam mencapai penjualan yang maksimal.

Sejak berkembangnya dunia teknologi baik media sosial maupun E-Commerce, ritel konvensional semakin di tinggalkan oleh pelanggan. Masyarakat lebih suka berbelanja dengan menggunakan teknologi, berbagai kemudahan yang di dapatkan untuk mendapatkan barang belanjaannya dan hanya cukup dengan berada dirumah tanpa membuang waktu untuk datang langsung ke toko. Hal ini membuat peritel semakin kesulitan mempertahankan pelangannya. Berdasarkan hal inilah maka penulis tertarik mengambil judul "Pengaruh 
Kemajuan Teknologi Terhadap Volume Penjualan Ritel Di Kota Mojokerto".

\section{RUMUSAN MASALAH}

Berdasarkan latar belakang permasalahan diatas dapat disimpulkan perumusan masalah sebagai berikut :

1. Bagaimanakah pengaruh media sosial dan E-Commerce terhadap volume penjualan Ritel di Kota Mojokerto secara simultan?

2. Bagaimanakah Pengaruh Media Sosial dan E-Commerce terhadap Volume Penjualan Ritel di Kota Mojokerto secara partial?

\section{TUJUAN PENELITIAN}

1. Untuk mengetahui pengaruh media sosial dan E-Commerce terhadap volume penjualan Ritel di Kota Mojokerto secara simultan.

2. Untuk mengetahui pengaruh media sosial dan E-Commerce terhadap volume penjualan Ritel di Kota Mojokerto secara partial.

\section{MANFAAT PENELITIAN}

Berdasarkan tujuan penelitian yang hendak dicapai, maka penelitian ini diharapkan mempunyai manfaat. Adapun manfaat penelitian ini adalah sebagai berikut :

1. Hasil penelitian ini diharapkan dapat memberikan dan menambah wawasan serta pengetahuan mengenai penerapan Media Sosial dan E-Commerce untuk dijadikan sarana sebagai alat untuk memasarkan barang dan produk mengembangkan ritel yang mampu bersaing di masa yang akan datang.

2. Diharapkan dapat berguna bagi para pengusaha Ritel dalam penerapan Media Sosial dan E-Commerce sehingga mampu bersaing dengan peritel lainnya.

\section{TINJAUAN PUSTAKA \\ Media Sosial}

Menurut Kamus Besar Bahasa Indonesia, media merupakan alat (sarana) komunikasi, perantara, atau penghubung. Jika dilihat pula dari asal katanya, 'Medius' (bahasa Latin) yang berarti 'tengah', maka dapat ditarik kesimpulan bahwa media mengarah pada sebuah sarana/ alat untuk yang digunakan untuk menyajikan informasi. Media sendiri banyak dipakai dalam berbagai bidang kehidupan manusia, terutama dalam proses pembelajaran. Media digunakan untuk mempermudah penyampaian informasi, sehingga pesan yang di sampaikan pemberi informasi dapat di terima dengan baik oleh penerima informasi.

Beberapa pengertian mengenai media sosial telah dirumuskan oleh berbagai pihak, baik dalam kajian komunikasi maupun kajian lain. Menurut Carr dan Hayes, definisi atau pengertian yang telah dirumuskan seringkali merujuk media sosial pada tiga hal utama, yaitu :

1. Teknologi digital yang menekankan pada user-generated content atau interaksi.

2. Karakteristik media.

3. Jejaring sosial seperti Facebook, Twitter, Instagram, dan lain-lain sebagai contoh model interaksi.

Jejaring sosial yang saat ini biasa digunakan untuk memasarkan produk antara lain Facebook, Twitter, Whats app dan instagram. Dengan melalui jejaring sosial tersebut akan terbentuk strategi komunikasi pemasaran yang efektif yaitu Word of Mouth dimana muncul secara natural dari pendapat lingkungan sosial yang dirasa lebih jujur dan tidak ada motifmotif tertentu dalam menyampaikan suatu informasi kepada konsumen lainnya.

Promosi merupakan salah satu unsur dari bauran pemasaran (marketing mix), disamping penetapan harga jual, produk, dan distribusi. Promosi sangat berpengaruh terhadap usaha perusahaan untuk mencapai volume penjualan yang maksimal, karena meskipun produk yang ditawarkan sudah baik, relatif murah serta mudah untuk diperoleh, jika tidak disertai promosi yang baik, maka tingkat penjualan tidak akan memadai.

Suatu usaha jika ingin mencapai tingkat penjualan yang maksimal, perusahaan 
dapat memakai beberapa macam bauran promosi (Kotler, 2002:644) yaitu : periklanan (Advertising), promosi penjualan (Sales promotion), hubungan masyarakat dan publisitas (Public relations), penjualan personal (Personal selling), dan pemasaran langsung (Direct marketing). Namun dari semua hal yang diharapkan dari promosi, perlu pula dipertimbangkan apakah biaya yang dikeluarkan oleh kegiatan promosi itu dapat memberikan pengaruh yang besar terhadap peningkatan penjualan dan sampai sejauh mana promosi itu dapat menarik konsumen untuk membeli produk yang ditawarkan.

Efektivitas promosi sangat tergantung dari pemilihan bentuk promosi yang diperlukan terhadap produk yang dipasarkannya. Suatu jenis produk tertentu memerlukan bentuk promosi tertentu pula dan jenis promosi yang lain harus dipergunakan bentuk promosi yang lain pula. Dengan kata lain tidak semua bentuk promosi dapat cocok dan menjamin keberhasilan promosi tersebut apabila tidak sesuai dengan kondisi yang dimiliki oleh suatu produk. Oleh karena itu, harus dicari suatu bentuk promosi yang sesuai dengan kondisi suatu produk yang akan dipromosikan.

\section{E-Commerce}

E-commerce merupakan suatu istilah yang sering digunakan atau didengar saat ini yang berhubungan dengan internet, dimana tidak seorangpun yang mengetahui jelas pengertian dari e-commerce tersebut. Berikut akan dipaparkan pengertian ecommerce menurut para ahli :

a. Perdagangan elektronik atau yang disebut juga e-commerce, adalah penggunaan jaringan komunikasi dan komputer untuk melaksanakan proses bisnis. Pandangan populer dari ecommerce adalah penggunaan internet dan komputer dengan browser Web untuk membeli dan menjual produk. McLeod Pearson (2008 : 59). b. Menurut Hidayat (2008:5) perdagangan eletronik (E-Commerce : Menurut Vermaat (2007:83) E-Commerce merupakan transaksi bisnis yang terjadi dalam jaringan elektronik seperti internet. Siapapun yang mempunyai jaringan internet dapat berpartisipasi dalam E-Commerce.

E-commerce juga melibatkan aktivitas yang berhubungan dengan proses transaksi elektronik seperti transfer dana elektronik, pertukaran data elektronik, sistim pengolahan data inventori yang dilakukan dengan sistem komputer ataupun jaringan komputer dan lain sebagainya. Dalam teknologi informasi e-commerce dapat dikategorikan sebagai bagian dari ebusiness dimana e-business memiliki cakupan lebih luas baik dari segi aktivitas.

E-commerce dibedakan menjadi beberapa jenis berdasarkan karakteristiknya yaitu:

1. Business to Business (B2B), Business to Business memiliki karakteristik:

a. Trading partners yang sudah saling mengetahui dan antara mereka sudah terjalin hubungan yang berlangsung cukup lama. Informasi yang dimiliki hanya ditukar dengan partner tersebut.

b. Pertukaran data dilakukan secara berulang-ulang dan berkala dengan format data yang telah disepakati bersama.

c. Salah satu pelaku tidak harus menunggu rekan mereka lainnya untuk mengirimkan data.

d. Model yang umum digunakan adalah peer to peer, di mana processing intelligence dapat didistribusikan di kedua pelaku bisnis.

2. Business to Consumer (B2C), Business to Consumer memiliki karakteristik :

a. Terbuka untuk umum, di mana informasi disebarkan secara umum pula dan dapat diakses secara bebas.

b. Servis yang digunakan bersifat umum, sehingga dapat digunakan oleh orang banyak. Sebagai contoh, 
karena sistem web sudah umum digunakan maka service diberikan dengan berbasis web.

c. Servis yang digunakan berdasarkan permintaan. Produsen harus siap memberikan respon sesuai dengan permintaan konsumen.

d. Sering dilakukan sistem pendekatan client-server.

3. Cosumer to Consumer $(\mathrm{C} 2 \mathrm{C})$, Dalam C2C seorang konsumen dapat menjual secara langsung barangnya kepada konsumen lainnya, atau bisa disebut juga orang yang menjual produk dan jasa ke satu sama lain. Mengiklankan jasa pribadi di internet serta menjual pengetahuan dan keahlian merupakan contoh lain C2C. sejumlah situs pelelangan memungkinkan perorangan untuk memasukkan item-item agar disertakan dalam pelelangan. Akhirnya, banyak perseorangan yang menggunakan intranet dan jaringan organisasi untuk mengiklankan itemitem yang akan dijual atau juga menawarkan aneka jasa

4. Customer to Busines (C2B) Customer to Busines adalah model bisnis dimana konsumen (individu) menciptakan nilai, dan perusahaan mengkonsumsi nilai ini. Sebagai contoh, ketika konsumen menulis review, atau ketika konsumen memberikan ide yang berguna untuk pengembangan produk baru, maka individu ini adalah yang menciptakan nilai bagi perusahaan, jika perusahaan tersebut mengadopsi inputnya. Sebagai contoh, Priceline.com merupakan situs yang memungkinkan seseorang menjual barang kepada perusahaan. Dalam hal ini, internet dapat digunakan sebagai sarana negosiasi.

\section{Volume Penjualan}

Menurut Freddy Rangkuti dalam Ericson Damanik (2013), volume penjualan adalah pencapaian yang dinyatakan secara kuantitatif dari segi fisik atau volume atau unit suatu produk. Dalam kegiatan pemasaran kenaikan volume penjualan merupakan ukuran efisiensi, meskipun tidak setiap kenaikan volume penjualan diikuti dengan kenaikan laba. Jadi dapat diartikan bahwa volume penjualan adalah jumlah dari kegiatan penjualan suatu produk atau jasa yang dihasilkan oleh perusahaan dalam suatu ukuran waktu tertentu.

Hasil kerja dalam penjualan diukur dari volume penjualan yang dihasilkan dan bukan dari laba pemasaran. Perusahaan yang berorientasi pada penjualan ini menganut sebuah konsep yang disebut konsep penjualan. Menurut: Suyanto (2007:14), konsep penjualan menyatakan bahwa konsumen akan membeli produk ke ritel jika melakukan promosi dan penjualan yang menonjol.

Menurut Kotler dalam Hakim Simanjuntak (2013), faktor-faktor yang mempengaruhi volume penjualan adalah sebagai berikut:

1. Harga jual, Faktor harga jual merupakan hal-hal yang sangat penting dan mempengaruhi penjualan atas barang atau jasa yang dihasilkan. Apakah barang atau jasa yang ditawarkan oleh perusahaan dapat dijangkau oleh konsumen sasaran.

2. Produk, Produk salah satu faktor yang mempengaruhi tingkat volume penjualan sebagai barang atau jasa yang ditawarkan oleh perusahaan apakah sesuai dengan tingkat kebutuhan para konsumen.

3. Biaya promosi, Biaya promosi adalah akktivitas-aktivitas sebuah perusahaan yang dirancang untuk memberikan informasi-informasi membujuk pihak lain tentang perusahaan yang bersangkutan dan barang-barang serta jasa-jasa yang ditawarkan.

4. Saluran Distribusi, Merupakan aktivitas perusahaan untuk menyampaikan dana menyalurkan barang yang ditawarkan oleh perusahaan kepada konsumen yang diujinya.

5. Mutu, Mutu dan kualitas barang merupakan salah satu faktor yang 
mempengaruhi volume penjualan. Dengan mutu yang baik maka konsumen akan tetap loyal terhadap produk dari perusahaan tersebut, begitu pula sebaliknya apabila mutu produk yang ditawarkan tidak bagus maka konsumen akan berpaling kepada produk lain.

\section{KERANGKA KONSEPTUAL DAN HIPOTESIS}

Selanjutnya secara sistematis kerangka konseptual penelitian yang akan dilakukan oleh penulis dapat digambarkan sebagai berikut :

\section{Gambar: 3.1 Kerangka Pemikiran Peneliti}

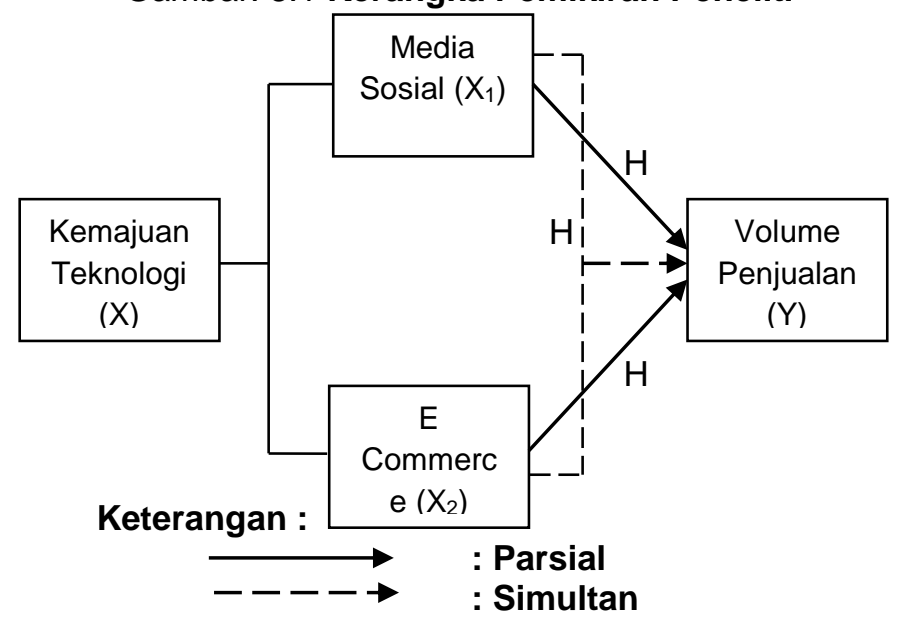

\section{Hipotesis}

Berdasakan kerangka konseptual diatas, penulis membuat hipotesis sebagai berikut

1. $\mathrm{H}_{1}$ : Media Sosial dan E Commerce memiliki pengaruh signifikan terhadap Volume Penjualan secara Simultan.

2. $\mathrm{H}_{2}$ : Media Sosial dan E Commerce memiliki pengaruh signifikan terhadap Volume penjualan secara Partial.

\section{METODE PENELITIAN Jenis Penelitian}

Jenis penelitian yang digunakan dalam penelitian ini adalah penelitian kuantitatif dengan metode studi Kasus, yang bertujuan mengumpulkan data dan informasi serta mendeskripsikan objek penelitian untuk memperolah gambaran secara mendalam dan objektif mengenai kemajuan teknologi terhadap volume penjualan ritel sepatu dan accesoris di kota mojokerto.

\section{Teknik Pengambilan Sampel}

Penentuan sampel dalam penelitian ini menggunakan kombinasi dari beberapa metode atau teknik pengambilan sampel.

( Sugiyono, 2006:89 ). Penentuan sampel dilakukan melalui purposif (purposive sampling). Secara purposif, pengambilan sampel harus menjaring 2 sifat atau kriteria yang diminta dan sesuai dengan maksud dan tujuan dalam penelitian. Kriteria-kriteria yang dimaksud tersebut antara lain:

1. Pemilik, Pengelolah dan Karyawan Ritel.

2. Ritel Sepatu dan Accessoris di Kota Mojokerto lebih dari 10 tahun.

\section{Teknik Pengukuran Variabel}

a. Uji Validitas

Menurut Arikunto (2006:168) validitas adalah suatu ukuran yang menunjukan tingkat kevalidan atau kesahihan suatu instrumen.

Uji validitas bertujuan untuk mengetahui bahwa item pertanyaan dengan variabel-variabel adalah valid atau validitas konstruk. Validitas instrument dinilai berdasarkan standar signifikan korelasi <0,05. Sugiyono (2010:356), Syarat minimum untuk dianggap memenuhi syarat adalah kalau $r=0,3$. Jadi, jika korelasi antara butir dengan skor total kurang dari 0,3 maka butir tersebut tidak valid.

\section{b. Uji Reliabilitas}

Uji realibilitas dimaksudkan untuk mengetahui sejauh mana hasil pengukuran tetap konsisten apabila dilakukan pengukuran dua kali atau lebih terhadap pernyataan yang sama menggunakan alat ukur yang sama pula. Reliabilitas menyangkut ketepatan alat ukur apakah suatu alat ukur sudah cukup akurat, stabil, dan konsisten dalam mengukur apa yang ingin diukur. Instrumen yang sudah dapat 
dipercaya, yang reliabel akan menghasilkan data yang dapat dipercaya juga (Arikunto, 2006:178).

Instrumen yang dipakai untuk menguji kehandalan suatu instrumen digunakan formula alfa cronbach. Suatu instrumen tersebut dikatakan reliable (reliable) apabila memiliki cronbach alpha lebih dari 0,60 atau $60 \%$.

\section{c. Uji F (F-tes)}

Bertujuan untuk mengetahui pengaruh secara simultan atau bersama-sama antara variabel independent terhadap variebel dependent. Pada uji ini menggunakan SPSS IMB 20. Tingkat signifikan yang digunakan adalah $\alpha=5 \%$.

\section{d. Uji T (t-tes)}

Analisis ini digunakan untuk mengetahui ada tidaknya pengaruh veriabel independent terhadap variabel dependent secara parsial. Pada uji ini menggunakan SPSS 20.0. Tingkat signifikan yang digunakan adalah $\alpha=5 \%$.

\section{e. Uji Asumsi Klasik}

Uji Normalitas Menurut Imam Ghozali (2013:110) tujuan dari uji normalitas adalah sebagai berikut: "Uji normalitas bertujuan untuk mengetahui apakah masing-masing variabel berdistribusi normal atau tidak. Uji normalitas diperlukan karena untuk melakukan pengujian-pengujian variabel lainnya dengan mengasumsikan bahwa nilai residual mengikuti distribusi normal. Jika asumsi ini dilanggar maka uji statistik menjadi tidak valid dan statistik parametrik tidak dapat digunakan." Dasar pengambilan untuk uji normalitas data adalah:

1. Jika data menyebar garis diagonal dan mengikuti garis diagonal atau grafik histogramnya menunjukkan distribusi normal, maka model regresi memenuhi asumsi normalitas.

2. Jika data menyebar jauh dari diagonal dan/atau tidak mengikuti arah garis diagonal atau grafik histogram tidak menunjukkan distribusi normal, maka model regresi tidak memenuhi asumsi normalitas.
Uji Heteroskedastisitas Menurut Imam Ghozali (2013:105) Uji heteroskedastisitas bertujuan untuk menguji apakah dalam model regresi terjadi ketidaksamaan variance dari residual satu pengamatan ke pengamatan lain, jika variance dari residual satu pengamatan ke pengamatan lain berbeda maka disebut heteroskedastisitas. Dasar pengambilan keputusan untuk uji heteroskedastisitas :

1. Jika ada pola tertentu, seperti titik yang ada membentuk pola tertentu teratur (bergelombang, melebur kemudian menyempit), maka mengindikasikan telah terjadi heteroskedastisitas.

2. Jika tidak ada pola yang jelas, serta titik-titik menyebar diatas dan dibawahangka 0 pada sumbu Y, maka tidak terjadi heteroskedastisitas.

\section{HASIL PENELITIAN}

Berdasarkan hasil analisis dengan menggunakan teknik analisis linier berganda yang menggunakan program SPSS versi IMB 20 diperoleh hasil sebagai berikut :

\section{a. Uji Validitas}

Uji validitas bertujuan untuk mengetahui bahwa item pertanyaan dengan variabel-variabel adalah valid atau validitas konstruk. Validitas instrument dinilai berdasarkan standar signifikan korelasi $<0,05$.

\begin{tabular}{|c|c|c|c|}
\hline \begin{tabular}{l|l} 
Variabel & Indikator
\end{tabular} & signifikasi & Hasil u & \\
\hline \multirow[t]{4}{*}{ Sosial Media } & $\mathrm{X} 1.1$ & 0.000 & Valid \\
\hline & $\mathrm{X} 1.2$ & 0.000 & Valid \\
\hline & $\mathrm{X} 1.3$ & 0.000 & Valid \\
\hline & $\mathrm{X} 1.4$ & 0.000 & Valid \\
\hline \multirow[t]{4}{*}{ E Commerce } & $\mathrm{X} 2.1$ & 0.000 & Valid \\
\hline & $\mathrm{X} 2.2$ & 0.000 & Valid \\
\hline & $\mathrm{X} 2.3$ & 0.000 & Valid \\
\hline & $\mathrm{X} 2.4$ & 0.000 & Valid \\
\hline \multirow[t]{5}{*}{ Volume Penjualan } & Y1.1 & 0.000 & Valid \\
\hline & $\mathrm{Y} 1.2$ & 0.000 & Valid \\
\hline & Y1.3 & 0.000 & Vakid \\
\hline & Y1.4 & 0.000 & Valid \\
\hline & Y1.5 & 0.000 & Valid \\
\hline
\end{tabular}

disimpulkan bahwa nilai signifikan kurang 
dari 5\%, maka semua variabel dapat dkatakan valid.

\section{b. Uji Reliabilitas}

Pengujian ini di gunakan untuk mengetahui kehandalan suatu instrumen. Dengan melihat alfa cronbach, jika nilai lebih dari 6\% maka dikatakan reliabel.

\begin{tabular}{|l|l|l|}
\hline Variabel & alfa cronbach & Hasil uji \\
\hline Media Sosial & 0,814 & Reliabel \\
\hline E Commerce & 0,795 & Reliabel \\
\hline Volume Penjualan & 0,830 & Reliabel \\
\hline
\end{tabular}

Berdasarkan tabel di atas dapat disimpulkan bahwa hasil pengujian mempunyai nilai alfa cronbach lebih besar dari $6 \%$, maka semua variabel di katakan memenuhi syarat dan reliabel.

c. Uji F (F-tes)

Agar dapat diketahui apakah variabel independent secara simultan (bersama-sama) mempunyai pengaruh terhadap variabel dependent atau tidak, maka digunakan Uji $\mathrm{F}$ (Uji Simultan) yaitu dengan cara membandingkan nilai signifikansi dengan $\alpha$ (5\%) atau tingkat kepercayaan sebesar 95\% dengan kriteria: Jika Sig. $F<\alpha$, maka Ho diterima dan $\mathrm{Ha}$ ditolak, Jika Sig. $\mathrm{F}>\alpha$, maka Ho ditolak dan $\mathrm{Ha}$ diterima.

\begin{tabular}{|l|r|r|r|r|r|}
\hline Model & \multicolumn{1}{|c|}{ ANOVA $^{\mathrm{a}}$} \\
& Squares & df & $\begin{array}{r}\text { Mean } \\
\text { Square }\end{array}$ & F & Sig. \\
\hline Regression & 12,274 & 2 & 6,137 & 25,385 &, $000^{\mathrm{b}}$ \\
1 Residual & 7,253 & 30 &, 242 & & \\
Total & 19,527 & 32 & & & \\
\hline
\end{tabular}

a. Dependent Variable: Volume Penjualan

b. Predictors: (Constant), E Commerce, Sosial Media

\begin{tabular}{|l|c|r|r|r|}
\hline Model & $R$ & $R$ Square & $\begin{array}{c}\text { Adjusted R } \\
\text { Square }\end{array}$ & $\begin{array}{c}\text { Std. Error of the } \\
\text { Estimate }\end{array}$ \\
\hline 1 &, $793^{\mathrm{a}}$ &, 629 &, 604 &, 49170 \\
\hline
\end{tabular}

a. Predictors: (Constant), E Commerce, Sosial Medi

Berdasarkan hasil pengujian pada tabel Anova dan summary diatas menunjukkan bahwa variabel Media Sosial dan variabel E-Commerce berpengaruh dan signifikan terhadap variabel Volume Penjualan secara simultan dengan nillai $\mathrm{F}$ sebesar 25.385 dan tingkat signifikan sebesar 0.000 yang lebih kecil dari 5\%. Dan dapat menjelaskan bahwa variabel independent berpengaruh terhadap variabel dependent sebesar 0.629 atau $62.9 \%$, sisanya di pengaruhi variabel lain.

\section{d. Uji T (T-tes)}

Uji t dilakukan untuk menguji secara parsial apakah variabel Sosial media dan variabel E-Commerce berpengaruh signifikan terhadap variabel Volume Penjualan dengan kreteria: Ho diterima jika $t_{\text {hitung }}<\mathrm{t}_{\text {tabel }}$, dan Ho ditolak jika $\mathrm{t}_{\text {hitung }}$ $>t_{\text {tabel }}$ pada $\alpha=5 \%$.

\begin{tabular}{|c|c|c|c|c|c|}
\hline \multicolumn{6}{|c|}{ Coefficients $^{a}$} \\
\hline \multirow[t]{2}{*}{ Model } & \multicolumn{2}{|c|}{$\begin{array}{l}\text { Unstandardized } \\
\text { Coefficients }\end{array}$} & \multirow{2}{*}{$\begin{array}{c}\begin{array}{c}\text { Standardized } \\
\text { Coefficients }\end{array} \\
\text { Beta }\end{array}$} & \multirow[t]{2}{*}{ t } & \multirow[t]{2}{*}{ Sig. } \\
\hline & $B$ & $\begin{array}{l}\text { Std. } \\
\text { Error }\end{array}$ & & & \\
\hline (Constant) & 1,961 & ,370 & & 5,304 &, 000 \\
\hline $1 \begin{array}{r}\text { Sosial } \\
\text { Media }\end{array}$ & 342, & 099, & 625, & 3,467 & 000, \\
\hline $\begin{array}{l}\text { E } \\
\text { Commerce }\end{array}$ & 174, & , 157 & 200, & 1,111 & ,016, \\
\hline
\end{tabular}

Berdasarkan tabel diatas, dapat dijelaskan bahwa variabel Media Sosial dan variabel E-Commerce berpengaruh dan signifikan secara parsial terhadap variabel Volume Penjualan dengan nilai sebesar 5.304 dan tingkat signifikan sebesar 0.000 yang lebih kecil dari $5 \%$. Pada variabel Sosial Media mempunyai pengaruh pada variabel Volume Penjualan sebesar 3.467 dengan tingkat signifikan sebesar 0.000 yang lebih kecil dari $5 \%$. Dapat diartikan apabila dinaikkan satu satuan maka volume penjualan akan naik sebesar 3.467 atau 34.67\%. Dan pada variabel E-Commerce berpengaruh pada volume penjualan sebesar 1.111 dengan tingkat signifikan sebesar 0.016 yang lebih kecil dari 5\%. Dapat diartiakan apabila dinaikkan satu satuan maka volume penjualan naik sebesar 1.111 atau $11.11 \%$.

\section{e. Uji Asumsi Klasik}

Tujuan dari uji normalitas untuk mengetahui apakah masing-masing variabel berdistribusi normal atau tidak. Uji normalitas diperlukan karena untuk melakukan pengujian-pengujian variabel lainnya dengan mengasumsikan bahwa 
nilai residual mengikuti distribusi normal. Jika asumsi ini dilanggar maka uji statistika menjadi tidak valid dan statistika parametik tidak dapat digunakan.

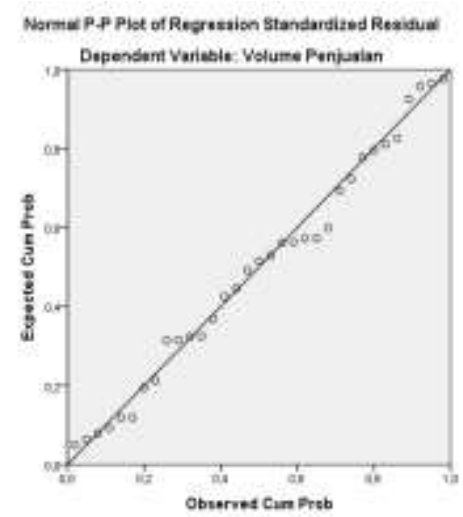

Dari hasil output chart diatas, dapat dilihat bahwa titik-titik yang ada selalu mengikuti garis diagonalnya. Oleh karena itu, dapat di simpulkan bahwa nilai residual berdistribusi normal sehingga syarat normalitas nilai residual untuk analisis regresi dapat terpenuhi.

Tujuan dari Uji Heteroskedastisitas untuk menguji terjadinya perbedaan variance dari nilai residual pada suatu periode pengamatan ke periode pengamatan yang lainnya.

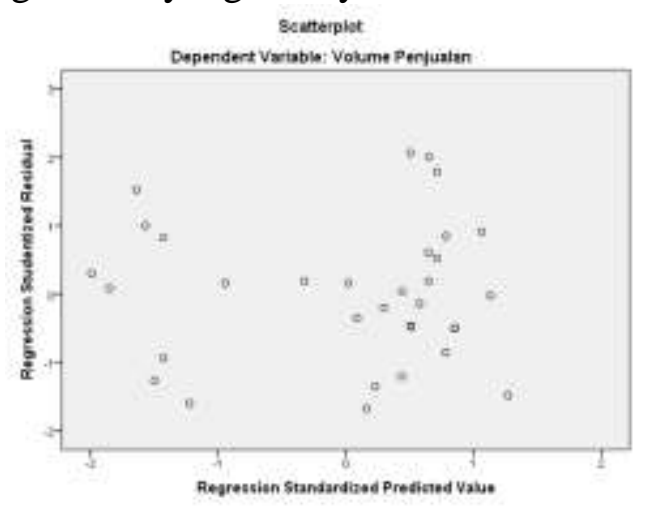

Dari hasil output scatterplots diatas diketahui bahwa telah memenuhi syarat pada uji heteroskedastistas. Dengan demikian dapat disimpulkan tidak terjadi masalah heteroskedastistas, sehingga model regresi yang baik dan ideal dapat terpenuhi.

\section{PEMBAHASAN}

Hasil dari analisis diatas menunjukkan bahwa volume penjual pada Ritel di kota mojokerto di pengaruhi oleh Media Sosial dan E-Commerce.

1. Berdasarkan hasil penelitian menunjukkan bahwa pengaruh media sosial dan e-commerce secara simultan mempunyai pengaruh terhadap volume penjualan sebesar 6.29 atau $62.9 \%$. Di artiakan bahwa media sosial dan ecommerce berpengaruh terhadap volume penjualan ritel sebesar $62.9 \%$. sehingga untuk meningkatkan Volume Penjualan, maka pemilik, pengelola, dan karyawan diharuskan lebih aktif mempromosikan barang dagangan melalui Media Sosial dan juga menjual barang dagangan melalui E-Commerce yang sudah menjadi trend di kalangan masyarakat.

2. Berdasarkan hasil penelitian menunjukkan bahwa pengaruh Media Sosial dan E-Commerce secara parsial berpengaruh terhadap Volume Penjualan. Hasil penelitian Pengaruh media sosial terhadap volume penjualan sebesar 3.467 atau $34.67 \%$ menunjukkan bahwa dari penjualan ritel tersebut di pengengaruhi oleh penjualan lewat media sosial. Maka dari itu, Untuk meningkatkan volume penjualan pada ritel maka pemilik, pengelola dan juga karyawan harus lebih aktif menggunaan media sosial sebagai sarana mempromosikan produk dan barang dagangannya, agar dapat mudah dikenal oleh konsumen. Sedangkan pengaruh E-Commerce terhadap volume penjualan sebesar 1.111 atau $11.11 \%$, menunjukan bahwa penjualan dari ritel di pengangaruhi oleh ECommerce sebesar $11.11 \%$. Dengan adanya e-commerce pola jual beli di masyarakat mulai berubah. Banyak ritel memanfaatkan untuk menjual barang daganganya melalui e-commerce, sebab jangkauan zona penjualan yang bertambah luas dan bisa diketahui seluruh masyarakat. Sebab dengan kemajuan teknologi pada saat ini 
komsumen tidak harus datang langsung pada ritel untuk mengetahui produk terbaru serta harga yang lebih ideal melainkan hanya melihat pada media sosial dan apikasi jual beli online pada smartphone yang mereka punya.

3. Berdasarkan hasil penelitian diatas di ketahui bahwa variabel media sosial menjadi variabel paling dominan yang mempengaruhi volume penjualan dengan nilai pengaruh sebesar 3.467 atau $34.67 \%$ yang lebih besar dari nilai pengaruh variabel E-Commerce. Dapat diartikan apabila Media Sosial merupakan media promosi yang bisa membantu dan meningkatkan Volume Penjualan. Maka dari itu, dalam peningkatan penjualan ritel dibutuhkan lebih aktif untuk mempromosikan barang dagangannya melalui media sosial. Sebab dengan promosi melalui Media Sosial lebih efektif.

\section{SIMPULAN}

Berdasarkan hasil penelitian dan pembahasan, menghasilkan kesimpulan sebagai berikut :

1. Terdapat Penggaruh antara variabel Media Sosial dan E-Commerce terhadap Volume Penjualan Ritel secara simultan. Hal ini dibuktikan dengan nilai signifikan dari hasil uji $\mathrm{F}$ yang kurang atau lebih keci dari $5 \%$.

2. Variabel Media Sosial dan E Commerce berpengaruh terhadap Volume Penjualan secara parsial. Hal ini di buktikan dengan nilai signifikan dari hasil uji $\mathrm{T}$ yang kurang atau lebih kecil dari $5 \%$.

3. Diketahui bahwa Media Sosial mempunyai pengaruh paling dominan terhadap Volume Penjualan dibanding denga E-Commerce. Hal ini di buktikan niai dari hasil uji $\mathrm{T}$ yang lebih besar dari nilai E-Commerce.

\section{SARAN}

Untuk meningkatkan volume penjualan ritel, maka pemilik, pengelola dan karyawan lebih aktif mempromosikan barang dagangan melalui media sosial yang sudah ada, baik memalui facebook, whats app dan juga instagram, tidak bisa di pungkiri masyarakat lebih suka menggunakan media sosialnya untuk melihat dan mendapatkan barang yang di inginkan, sebab media sosial juga bisa dijadikan sebagai alat untuk mempromosikan yang lebih akurat dan praktis serta murah. Dan juga lebih diharapkan untuk meningkatkan penjualan melalui E-Commerce yang sudah banyak di gunakan sebagai tujuan masyarakat untuk mendapatkan barang yang diinginkan. Peritail diharapkan bisa memanfaatkan e-commerce yang sudah ada, seperti jualbeli.com, blibli.com, tokopedia dan lain lain untuk giat mempromosikan barang dagangannya, sebab Jangkauan e-commerce lebih luas dan bisa di kenal pada masyarakat di luar daerah dan juga bahkan bisa dikenal se Indonesia.

\section{DAFTAR PUSTAKA}

Arikunto, Suharsini. 2006. Prosedur Penelitian. Jakarta: Rineka Cipta.

Astrid, Dewi Kusumastuti. 2009. Sikap Terhadap Pengguna Facebook. Masterthesis. Jakarta: Universitas Bina Nusantara.

Carr, Caleb T dan Rebecca A Hayes. 2015. "Social Media: Defining, Developing, and Atlantic" Journal of Communication.

Ericso, Damanik. 2013. Pengertian Volume Penjualan. Jakarta: Indeks Kelompok Gramedia.

Fandy, Tjiptono. 2008. Strategi Pemasaran. Yogyakarta: Andi.

Freddy, Rangkuti. 2009. Pengertian Promosi. Jakarta: Gramedia Pustaka Utama.

Ghozali, Imam. 2013. Aplikasi Analisis Multivariate dengan Program SPSS. Semarang: BP Undip Semarang. 
http://mashable.com/2010/03/02/smallbusiness-stats/. Diakses 12 Januari 2018 pukul 12:46 WIB.

http://bebmen.com/4027/statistik-internetsosial-media-dan-mobile-di indonesia.html. Diakses 13 September 2018 pukul 17:39 WIB. Hidayat, Taufik. 2008. Panduan Membuat Toko Online dengan OS Commerce. Jakarta: Mediakita.

Kaplan, M. dan Haenlein Michael. 2010. "Users of the world, unite! The challenges and opportunities of social media". Business Horizons Volume 53 Number 2 Page 61.

Kottler, Philip. 2002. Manajemen Pemasaran. Jakarta: Prenhallindo.

Kottler, Philip, et.al. 2003. Rethinking Marketing, Sustainable Market-ing Enterprise di Asia. Jakarta: Prenhallindo.
Kottler, Philip. 2009. Manajemen Pemasaran. Jakarta: Macanan Jaya Cemerlang.

Sugiyono. 2006. Metode Penelitian Kuantitatif, Kualitatif dan $R \& D$. Bandung: Alvabeta.

Sugiyono. 2010. Metode Penelitian Kuantitatif, Kualitatif dan $R \& D$. Bandung: Alvabeta.

Simanjuntak, Hakim. 2013. Faktor-Faktor yang Mempengaruhi Volume Penjualan. Jakarta: Indeks Kelompok Gramedia.

Sunyoto. D. 2013. Dasar-dasar Manajemen Pemasaran. Yogyakarta: CAPS.

Suyanto, M. 2007. Marketing Strategy Top Brand Indonesia. Yogyakarta: Andi Offset. 